\title{
Analisis Pemerangkapan radikal bebas ekstrak etanol buah beringin (Ficus benjamina Linn.)
}

\author{
Marlina Karundeng ${ }^{a}$,Anderson Arnold Aloanis ${ }^{* a}$ \\ a Kimia, FMIPA, Universitas Negeri Manado, Tondano, 95618, Indonesia
}

\begin{tabular}{l} 
I N F O A R T I K E L \\
\hline Diterima 17 Juli 2018 \\
Disetujui 31 Juli 2018 \\
\hline Key word: \\
Free radical \\
Fruit \\
Ficus benjamina \\
DPPH \\
\hline Kata kunci: \\
Radikal bebas \\
Buah \\
Ficus Benjamina \\
DPPH \\
\hline \\
\\
${ }^{*} e$-mail: \\
marlinakarundeng@unima.ac.id \\
${ }^{*}$ Telp: 08114320980
\end{tabular}

\author{
A B S T R A C T \\ Fruit is a source of natural antioxidants are most plentiful. This research aims to analyze the \\ ability of fig fruit (Ficus benjamina Linn.) to scavenge 2.2-diphenyl-1-pikrilhidrazil. Ripe fig \\ fruit macerated with ethanol for $3 \times 24$ hours and evaporated. Ethanol extract of fig fruit then \\ tested for free radical scavenging activities and changes colour is measured by Spectrophotometer \\ UV-Vis. Ethanol extracts of Ficus Benjamina. Linn. shows IC 50 of $40.36 \mu \mathrm{g} / \mathrm{mL}$.
}

\begin{abstract}
A B STRAK
Buah merupakan sumber antioksidan alami yang paling banyak dijumpai. Penelitian ini bertujuan untuk menganalisis kemampuan pemerangkapan 2,2-difenil-1-pikrilhidrazil oleh buah beringin (Ficus benjamina Linn.). Buah beringin yang sudah matang dimaserasi dengan etanol selama $3 \times 24$ jam dan dievaoprasi. Ekstrak kental etanol buah beringin kemudian diuji aktivitas pemerangkapan radikal bebas dan perubahan warnanya diukur dengan Spektrofotometer UV-Vis. Ekstrak etanol Ficus Benjamina Linn. menunjukkan IC50 sebesar $40.63 \mu \mathrm{g} / \mathrm{mL}$.
\end{abstract}

\section{Pendahuluan}

Radikal bebas merupakan molekul atau fragmen molekul yang memiliki elektron yang tidak berpasangan pada orbit terluarnya. Radikal bebas dihasilkan dari pemutusan homolitik. Hal ini ada terjadi secara alami dan ada yang terbentuk dengan campur tangan manusia. Dalam tubuh yang sehat radikal bebas diimbangi oleh sistem imun, dan ketika sistem imun tidak mampu menangkalnya maka jaringan tubuh akan rusak melalui reaksi oksidasi. Kerusakan yang disebabkan oleh oksidasi radikal bebas pada sel hidup menyebabkan penyakit-penyakit kronis seperti penyakit parkinson, penyakit alzheimer, kanker, penuaan, serangan jantung, penyakit kardiovaskular, katarak, peradangan, dan beberapa penyakit lainnya [1].

Ficus benjamina merupakan tanaman tropis yang dapat kita jumpai dalam kehidupan sehari-hari. Ficus benjamina Linn sering diambil daun dan akar gantungnya untuk dijadikan obat radang, nyeri, batuk, dan malaria [2]. Akar, batang dan daun F. benjamina Linn. memiliki aktivitas antioksidan [3, 4].

\section{Bahan dan Metode}

Alat yang digunakan adalah Spektrofotometer UV-Vis (perkin elmer Lambda 25), pipet tetes, pipet mikro, tabung reaksi, labu takar, water bath. Bahan yang digunakan adalah metanol Pro analisis (merck) dan 2,2-difenil-1-pikrilhidrazil (sigma aldrich). Sampel yang digunakan adalah buah beringin (F. Benjamina Linn.) yang diambil pada saat buah sudah matang.

Tahapan uji pemerangkapan radikal bebas

Analisis pemerangkapan radikal bebas ekstrak etanol buah F. benjamina dibuat sesuai 
dengan metode yang dilakukan oleh kasangana (2015) dengan beberapa modifikasi [5]. Masingmasing sampel dan standard ditimbang sebanyak sepuluh miligram, dilarutkan dalam sepuluh mililiter metanol sehingga diperoleh larutan induk sebesar $1000 \mu \mathrm{g} / \mathrm{mL}$. Pipet masing-masing $25,50,75$, dan $125 \mu \mathrm{L}$ larutan induk ke dalam tabung reaksi. Untuk standar (asam askrobat) dipipet masing-masing 2.5, 12.5, 25, 37.5 dan $50 \mu \mathrm{L}$. Metanol ditambahkan hingga $2000 \mu \mathrm{L}$ sehingga diperoleh konsentrasi larutan sebesar , 10, 20, 30, dan $50 \mu \mathrm{g} / \mathrm{mL}$ untuk masing-masing sampel dan 1,5,10, dan 15 $\mu \mathrm{g} / \mathrm{mL}$ untuk standar. DPPH ditimbang sebanyak $\pm 8 \mathrm{mg}$, dilarutkan dalam $50 \mathrm{ml}$ metanol p.a. Pipet larutan DPPH sebanyak 500 $\mu \mathrm{L}$ ke dalam tabung reaksi. Untuk konsentrasi 0 $\mu \mathrm{g} / \mathrm{mL}$ larutan DPPH dimasukkan sebanyak $500 \mu \mathrm{L}$ dan tambahkan $2000 \mu \mathrm{L}$ metanol. Semua sampel diinkubasi pada suhu $37^{\circ} \mathrm{C}$ selama 30 menit. Diukur dengan menggunakan spektrofotometer pada panjang gelombang $516.5 \mathrm{~nm}$. Nilai IC50 (konsentrasi ekstrak yang diperlukan untuk mengurangi $50 \%$ jumlah awal $\mathrm{DPPH})$ dihitung menggunakan analisis regresi [6].

\section{Hasil dan Pembahasan}

Buah beringin yang sudah matang diambil dan dimaserasi tanpa dikeringkan terlebih dahulu. Teknik ini digunakan untuk mengurangi resiko buah beringin yang akan berjamur dalam proses pengeringan. Kandungan air dalam buah beringin cukup besar dan memiliki resiko berjamur. Buah beringin ditimbang sebanyak 500 gram dan dihaluskan. Sampel dimaserasi dengan etanol $95 \%$ selama $3 \times 24$ jam. Setelah itu filtrat hasil maserasi di evaporasi dan menghasilkan ekstrak etanol buah beringin seberat 5.02 gram.

Ekstrak etanol buah beringin kemudian dianalisis kemampuan pemerangkapan radikal bebas 2,2-difenil-1-pikrilhidrazil. Setiap kon sentrasi dibuat dan diukur dengan tiga kali pengulangan.

Perubahan warna dari warna ungu menjadi warna kuning menunjukkan adanya aktivitas antioksidan [7]. Absorbansi dari setiap konsentrasi diukur dan dihitung persen inhibisinya dengan menggunakan rumus:

$$
\text { Inhibisi (\%) }=\frac{\mathrm{A}_{0}-\mathrm{A}_{1}}{\mathrm{~A}_{0}}
$$

Dimana Ao adalah abrorbansi 0 atau absorbansi DPPH dan A1 adalah absorbansi ekstrak etanol buah beringin [8].

Tabel 1. Absorbansi dan persen inhibisi ekstrak metanol buah beringin

\begin{tabular}{|c|c|c|}
\hline $\begin{array}{c}\text { Konsentrasi } \\
(\mu \mathrm{g} / \mathrm{mL})\end{array}$ & $\begin{array}{c}\text { Rata-rata } \\
\text { Absorbansi }\end{array}$ & $\begin{array}{c}\text { Persen } \\
\text { Inhibisi }\end{array}$ \\
\hline $\mathrm{DPPH}$ & 0.550 & \\
\hline 50 & 0.208 & $62.18 \pm 1.27$ \\
\hline 30 & 0.348 & $36.67 \pm 3.14$ \\
\hline 20 & 0.422 & $23.21 \pm 4.21$ \\
\hline 10 & 0.453 & $17.64 \pm 2.73$ \\
\hline
\end{tabular}

Dari rumus (i) diperoleh persen inhibisi dari ekstrak etanol buah beringin dan ditunjukkan dalam tabel 1. Hasil dari penghitungan persen inhibisi dikorelasikan dengan konsentrasi dan diperoleh kurva regresi (Gambar 1). Kurva ini menunjukkan $\mathrm{R}^{2}=0.9824$ dan diperoleh rumus $y=1.152 x+3.2433$ untuk menghitung IC 50 . Pada konsenstrasi $50 \mu \mathrm{g} / \mathrm{mL}$ ekstrak etanol mampu memerangkap $62.18 \pm$ 1.27 persen DPPH dan konsentrasi $30 \mu \mathrm{g} / \mathrm{mL}$ menunjukkan angka $36.67 \pm 3.14$ persen. Hal ini menunjukkan bahwa $\mathrm{IC}_{50}$ berada dibawah angka $50 \mu \mathrm{g} / \mathrm{mL}$. Antioksidan dikatakan sangat kuat bila memiliki IC $50>50 \mu \mathrm{g} / \mathrm{mL}$, untuk 50-100 $\mu \mathrm{g} / \mathrm{mL}$ dikatakan antioksidan kuat, 101-150 $\mu \mathrm{g} / \mathrm{mL}$ antioksidan sedang, dan dengan $\mathrm{IC}_{50}>$ $150 \mu \mathrm{g} / \mathrm{mL}$ dikatakan atioksidan yang lemah [9].

Hasil perhitungan regresi menunjukkan IC50 ekstrak etanol buah beringin sebesar 40.36 $\mu \mathrm{g} / \mathrm{mL}$. Aktivitas antioksidan ekstrak etanol buah beringin tergolong antioksidan yang kuat. Untuk vitamin C sebagai standar positif diperoleh $\mathrm{IC}_{50}$ sebesar $7.63 \mu \mathrm{g} / \mathrm{mL}$ merupakan antioksidan yang sangat kuat.

Aktivitas buah beringin Akrivitas ini lebih besar dibandingkan dengan kulit batang, daun, dan akar dari buah beringin [3,4]. Perbedaan pelarut saat ekstraksi bisa menjadi salah satu faktor pembeda. Pada penelitian sebelumnya menggunakan pelarut metanol dan penelitian 
ini menggunakan pelarut etanol. Selain itu banyaknya kandungan vitamin dalam buahbuahan dapat berpengaruh pada perbedaan aktivitas dari batang, daun, dan akar dibandingkan dengan bagian buah sebuah tumbuhan.

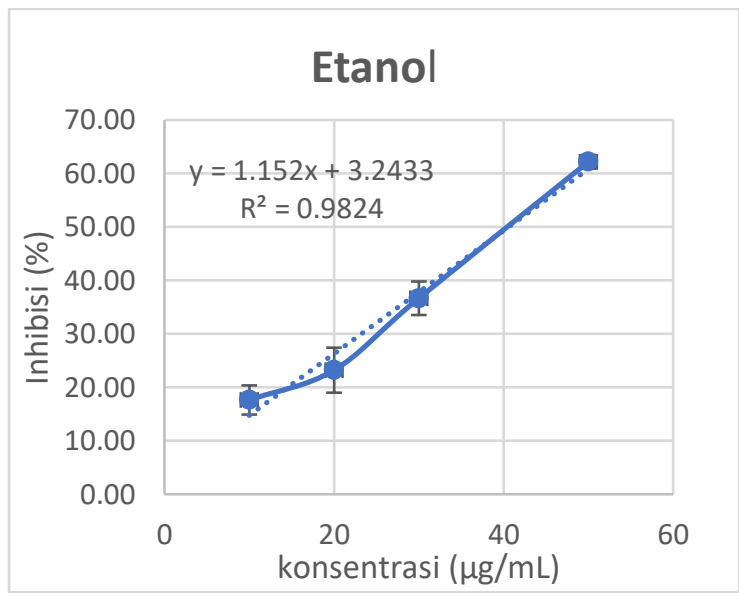

Gambar 1. kurva konsentrasi terhadap persen inhibisi ekstrak metanol buah beringin.

\section{Ucapan terimakasih}

Terima kasih kepada Direktorat Jenderal Penguatan Riset dan Pengembangan (Ditjen Risbang) Kementerian Riset Teknologi dan Pendidikan Tinggi untuk pembiayaan penelitian ini melalui skema Penelitian Dosen Pemula .

\section{Kesimpulan}

Dari hasil penelitian dapat disimpulkan bahwa Ekstrak metanol buah beringin memiliki IC50 sebesar $40.36 \mu \mathrm{g} / \mathrm{mL}$ terhadap DPPH.

\section{Daftar Pustaka}

1. Chanda, S.; Nagani, K., Antioxidant capacity of Manilkara zapota L. leaves extracts evaluated by four in vitro methods. Nature and science 2010, 8, (10), 260-266.

2. Abdelkader, A.; Aldughaish, A. M., Physiological and Chemical Characteristics of Age-Differed Ficus Benjamina L. Trees Cultivated in El-Ahassa, Saudi Arabia. Journal of Plant Sciences 2016, 4, (4), 63-67.

3. Imran, M.; Rasool, N.; Rizwan, K.; Zubair, M.; Riaz, M.; Zia-Ul-Haq, M.; Rana, U. A.; Nafady, A.; Jaafar, H. Z., Chemical composition and Biological studies of Ficus benjamina. Chemistry Central Journal 2014, 8, (1), 12.

4. Novelli, S.; Lorena, C.; Antonella, C.,
Identification of alkaloid's profile in Ficus benjamina L. extracts with higher antioxidant power. American Journal of Plant Sciences 2014, 5, (26), 4029.

5. Kasangana, P. B.; Haddad, P. S.; Stevanovic, T., Study of polyphenol content and antioxidant capacity of Myrianthus arboreus (Cecropiaceae) root bark extracts. Antioxidants 2015, 4, (2), 410-426.

6. Johty, S.; Zuraini, Z.; Sasidharan, S., Phytochemicals screening, DPPH free radical scavenging and xanthine oxidase inhibitory activities of Cassia fistula seed extract. Journal of Medicinal and Plants Research 2011, 5, 1941-1947.

7. Boligon, A. A.; Machado, M. M.; Athayde, M. L., Technical evaluation of antioxidant activity. Med chem 2014, 4, (7), 517-522.

8. Oktay, M.; Gülçin, İ.; Küfrevioğlu, Ö. İ., Determination of in vitro antioxidant activity of fennel (Foeniculum vulgare) seed extracts. LWT-Food Science and Technology 2003, 36, (2), 263-271.

9. Ahmad, I.; Sulistiarini, R.; Rijai, L., Antioxidant activity of some selected East Borneo plants. International Journal of Public Health Science (IJPHS) 2015, 4, (1), 58-62. 